\title{
KRAS mutations: variable incidences in a Brazilian cohort of 8,234 metastatic colorectal cancer patients
}

\author{
Carlos Gil Ferreira ${ }^{1,2,3^{*}}$, Veronica Aran², llana Zalcberg-Renault ${ }^{1,3}$, Ana Paula Victorino ${ }^{2,4}$, Jonas H Salem4, \\ Martin $\mathrm{H}$ Bonamino ${ }^{1,3}$, Fernando M Vieira ${ }^{2,4}$ and Mariano Zalis ${ }^{1}$
}

\begin{abstract}
Background: KRAS mutations are frequently found in colorectal cancer (CRC) indicating the importance of its genotyping in the study of the molecular mechanisms behind this disease. Although major advances have occurred over the past decade, there are still important gaps in our understanding of CRC carcinogenesis, particularly whether sex-linked factors play any role.

Methods: The profile of KRAS mutations in the Brazilian population was analyzed by conducting direct sequencing of KRAS codons 12 and 13 belonging to 8,234 metastatic CRC patient samples. DNA was extracted from paraffin-embedded tissue, exon 1 was amplified by PCR and submitted to direct sequencing. The data obtained was analysed comparing different geographical regions, gender and age.

Results: The median age was 59 years and the overall percentage of wild-type and mutated KRAS was $62.8 \%$ and $31.9 \%$, respectively. Interestingly, different percentages of mutated KRAS patients were observed between male and female patients (32.5\% versus 34.8\%, respectively; $p=0.03$ ). KRAS Gly 12 Asp mutation was the most prevalent for both genders and for most regions, with the exception of the North where Gly12Val was the most frequent mutation found.

Conclusions: To the best of our knowledge this is one of the largest cohorts of KRAS genotyping in CRC patients and the largest to indicate a higher incidence of KRAS mutation in females compared to males in Brazil. Nevertheless, further research is required to better address the impact of gender differences in colorectal cancer.
\end{abstract}

Keywords: KRAS, Mutation, Gender, Cohort, Colorectal cancer

\section{Background}

Personalised medicine is an evolving field that seeks to target cancer therapies based on unique genetic characteristics of the tumour and/or the patient [1]. One of the most significant advances towards personalised care in the field of oncology was the establishment of KRAS gene mutation as a validated biomarker predicting efficacy in epidermal growth factor receptor (EGFR) targeted therapies - such as cetuximab and panitumumab - in the treatment of metastatic colorectal cancer (mCRC) [2,3]. According to Siegel et al. [4], CRC is the third cause of

\footnotetext{
* Correspondence: cferreira@inca.gov.br

'Progenética Diagnósticos Moleculares, Av. Presidente Vargas, 9623 Andar, Cep: 20071-002 Rio de Janeiro, RJ, Brazil

${ }^{2}$ Brazilian National Cancer Institute (INCA); Coordenação de Pesquisa Clínica e Incorporação Tecnológica, Rio de Janeiro, Brazil

Full list of author information is available at the end of the article
}

new cancer cases and of death by cancer in the United States with an estimate of 73,420 new cases for males and 70,040 new cases for females in 2012. In Brazil, data published by the Brazilian National Cancer Institute predicted the number of new cases for 2012 of 14,180 for males and 15,960 for females with a frequency variation depending on the country's region (data available online at http://portal. saude.sp.gov.br/resources/ses/perfil/gestor/homepage/ estimativas-de-incidencia-de-cancer-2012/estimativas incidencia_cancer_2012.pdf). The Southeast region shows the highest incidence of $\mathrm{CRC}$, being the second most frequent cause of cancer for both men $(22 / 100,000)$ and women $(23 / 100,000)$. The differences observed in the incidence of CRC according to different Brazilian regions could relate to the idea that differences in patients origins 
might contribute to the incidence of somatic mutations in candidate cancer genes such as KRAS [5].

In order to understand $K R A S$ function it is important to address how Ras proteins are activated. The Ras protein family belongs to a group of small GTPases, which are able to cycle between an inactive (GDP-bound form) and an active state (GTP-bound form) leading to the activation of several effector kinases. These proteins are involved in cell proliferation, differentiation and survival, hence its importance in cancer research [6]. Mutations in $R A S$ proto-oncogenes (comprising $H-, N$ - and $K-R A S$ ) are among the most common in malignant tumours and although $R A S$ isoforms are very similar, KRAS is more frequently found mutated in cancers occurring in $22 \%$ of all tumours analysed compared to $8 \%$ for NRAS and $3 \%$ for $H R A S$ [7]. In mCRC, mutation in KRAS gene result in continuous activation of intracellular EGFR pathway regardless the pharmacological blocking of the receptor [8]. Thus, proliferation, invasion, survival and metastasis of the tumour are maintained. Clinically, patients with $K R A S$ wild-type tumours are more likely to respond to anti-EGFR therapy whereas those with mutant KRAS show lack of benefit [9-14]. Therefore, anti-EGFR monoclonal antibodies are only indicated in patients with KRAS wild-type tumours [15].

Since June 2008, a Merck Serono Oncology sponsored program began to reimburse for $K R A S$ mutation analyses in mCRC patients in Brazil. Almost all KRAS mutations tests were performed in a single molecular biology facility. A total of 8,234 patients had their primary tumour and/or metastasis analysed through the program. Here, some epidemiological characteristics of the KRAS mutations are described.

\section{Methods}

\section{Ethics statement}

The local ethical committee (Comitê de Ética em PesquisasCEP from Hospital Pró-Cardíaco, Esho Empresa de Serviços Hospitalares) was consulted and approved the analysis and publication of the epidemiological data without patient's individual informed consent.

\section{Merck Serono Oncology KRAS Program in Brazil}

Launched in June 2008, the Merck Serono Oncology KRAS Program invited physicians to request KRAS tests for any patient diagnosed with mCRC. Initially, the program was based in written formulary requests and telephone/fax contacts to provide authorizations for tests to be performed. In October 2009, the program was upgraded to internet-based process. All physicians had to accept the terms of the program, which comprehended no obligation in any kind of prescription and clarification to the patient that a pharmaceutical industry was covering the costs of the tests, having no contact with the identity of the patients or further individual results. After authorization was granted, the biological material (paraffin blocks and slides) was sent to the laboratory facility using Brazilian mail express services (SEDEX). The results were confidential and sent directly from the laboratory to the physician without report to Merck Serono.

\section{DNA extraction}

The tissue slide corresponding to the paraffin-embedded tumour block was analysed by a trained pathologist. The tumour area was marked and a fragment was digged out from the tissue block using proper stylet. The DNA extraction was performed using the commercial kit Magne$\mathrm{Sil}^{\mathrm{im}}$ (Promega Corporation, Madison, Wisconsin, USA) following manufacturer instructions described elsewhere.

\section{Polymerase chain reaction (PCR)}

Extracted DNA was analysed with semi-nested PCR. The primers utilized were: KRASF1 e KRASR. The first stage reactions were accomplished with $5 \mu \mathrm{l}$ of DNA, $2 \mu \mathrm{l} \mathrm{MgCl}(50 \mathrm{mM}), 5 \mu \mathrm{l}$ Promega 10× PCR Buffer, $2 \mu \mathrm{l}$ KRASF1 primer (5'-GTGTGACATGTTCTAATATAGT CA-3') $(50 \mathrm{pmol} / \mu \mathrm{l}), 2 \mu \mathrm{l}$ KRASR primer $\left(5^{\prime}\right.$-GAATGG TCCTGCACCAGTAA-3') (50 pmol/ $\mu \mathrm{l}), 5 \mu \mathrm{l}$ sNTPS (2,5 mM), 28,5 $\mu$ l distilled water, 0,5 $\mu$ l Taq Platinum DNA Pol (Invitrogen) in total volume of $50 \mu \mathrm{l}$, following a cycle program of $94^{\circ} \mathrm{C}$ for $1 \mathrm{~min}, 40$ cycles of $95^{\circ} \mathrm{C}$ during 20 seconds, $60^{\circ} \mathrm{C}$ during 30 seconds and $72^{\circ} \mathrm{C}$ for $1 \mathrm{~min}$ and 30 seconds and final extension of $20 \mathrm{~min}$ in $72^{\circ} \mathrm{C}$. For the semi-nested stage, the products from first stage PCR were diluted in 1:100 ratio in distilled water and $5 \mu \mathrm{l}$ were added to a mixture containing $5 \mu \mathrm{l}$ of DNA, $2 \mu \mathrm{l} \mathrm{MgCl}(50 \mathrm{mM}), 5 \mu \mathrm{l}$ Promega $10 \times$ PCR Buffer, $2 \mu \mathrm{l}$ KRASF primer $(50 \mathrm{pmol} / \mu \mathrm{l}), 2 \mu \mathrm{l}$ KRASF2 primer 5 ' -TCATTATTTTTATTATAAGGCCTGCTG-3' (50 pmol/ $\mu \mathrm{l}), 5 \mu \mathrm{l}$ sNTPS $(2,5 \mathrm{mM}), 28,5 \mu \mathrm{l}$ distilled water, $0,5 \mu \mathrm{l}$ Taq Platinum DNA Pol (Invitrogen) in total volume of $50 \mu \mathrm{l}$, in cycle conditions of $94^{\circ} \mathrm{C}$ during $1 \mathrm{~min}, 40$ cycles in $95^{\circ} \mathrm{C}$ for 20 seconds, $58^{\circ} \mathrm{C}$ for $30 \mathrm{sec}-$ onds and $72^{\circ} \mathrm{C}$ for $1 \mathrm{~min}$ and 30 seconds. All reactions were performed using MyCycler ${ }^{\mathrm{Tn}}$ Thermal Cycler (BioRad Laboratories, Inc; Hercules, CA, USA) equipment.

The PCR products were analysed in a $2 \%$ agarose gel and visualized under ultraviolet light. The samples were considered positive when the band correspondent to 185 base pairs was seen. After agarose gel electrophoresis, $40 \mu \mathrm{l}$ of PCR substrate was purified using commercial kit GFX $^{\mathrm{TM}}$ PCR DNA and Gel Purification Kit (GE Healthcare, Piscataway, NJ, USA) following manufacture's instructions.

\section{DNA sequencing}

The amount of $2 \mu \mathrm{l}$ of substrate was used in sequencing reactions using commercial kit BigDye Terminator v.3.1 Cycle Sequencing Kit (Applied Biosystems) according to 
manufacture's instruction using 3.2 pmol of oligo KRASR (5'-GAATGGTCCTGCACCAGTAA-3').

The sequences were analysed using $\mathrm{ABI} \mathrm{PRISM}^{\circ} 3100$ GeneticAnalyzer/HITACHI (Applied Biosystems) and the presence of mutations were performed using the Mutation Surveyor (Softgenetics) software.

\section{Statistical analysis}

Parameters evaluated were frequency of mutations, frequency of mutations per codons (12 or 13), types of mutations, gender, age, and geographic region distributions. Cross tabulation of interests combining some of the mentioned parameters were analysed whenever considered of interest.

Statistical analysis was performed using the Statistical Package for Social Sciences (SPSS software, version 13.0 for Windows, Chicago, IL, USA). The level of significance for $\mathrm{p}$ value was established as below $5 \%$.

Continuous variables were presented using mean values and standard deviation. The categorical variables were presented as absolute frequency and percentages. Further associations between variables were verified through Pearson's chi-square test.

\section{Results}

\section{Total frequency of wild-type versus mutant KRAS}

A total of 8,234 samples were pooled for analysis. There were 437 tests without a conclusive KRAS diagnostic. This occurred mostly due to inadequate samples that prevented DNA amplification related to fixation duration, type of formalin previously used and/or insufficient tumour availability. Whenever this occurred, up to four attempts of DNA extraction and amplification were performed before the physician requested more samples for analysis. Figure 1 displays the total frequencies of
KRAS mutations. Our results show an overall KRAS mutation frequency of $31.9 \%(\mathrm{n}=8,234)$.

\section{Analysis of KRAS according to regions}

Brazil has a territory of continental size showing a strong ancestral diversity: the result of interethnic crosses between different populations: the European colonizers (mainly Portuguese), African slaves and Amerindians [16]. For example, the Northeast region has a history of strong African presence due to slavery, the South was mostly settled by European immigrants and the North by Amerindians [17].

The Brazilian population admixture has important clinical implications [17]. Different population origins may determine different trends in gene mutations, therefore we analysed samples coming from patients from the five different regions of Brazil. The distribution of KRAS mutations according to geographic region is shown in Table 1. Each region showed more than 30\% incidence of KRAS mutant cases, being the Southeast the highest and the Northeast region the lowest in incidence. The distribution between genders of study population was well balanced between female (48.1\%) and male (51.9\%). The mean age of the population analysed was 58.8 years (standard deviation 13.02 range 14 to 102). The mean age for the presence of mutations was 60 years and for its absence, 59 years.

\section{Types of mutations and their geographical distribution}

After considering the different geographical regions and obtaining the result of mutant versus wild-type samples per region, we performed genotyping of KRAS codons 12 and 13, which are the most commonly affected codons in CRC also known to be predictors of resistance to anti-EGFR therapies [3]. By doing this, we accessed the frequent aminoacid changes. Although recent studies

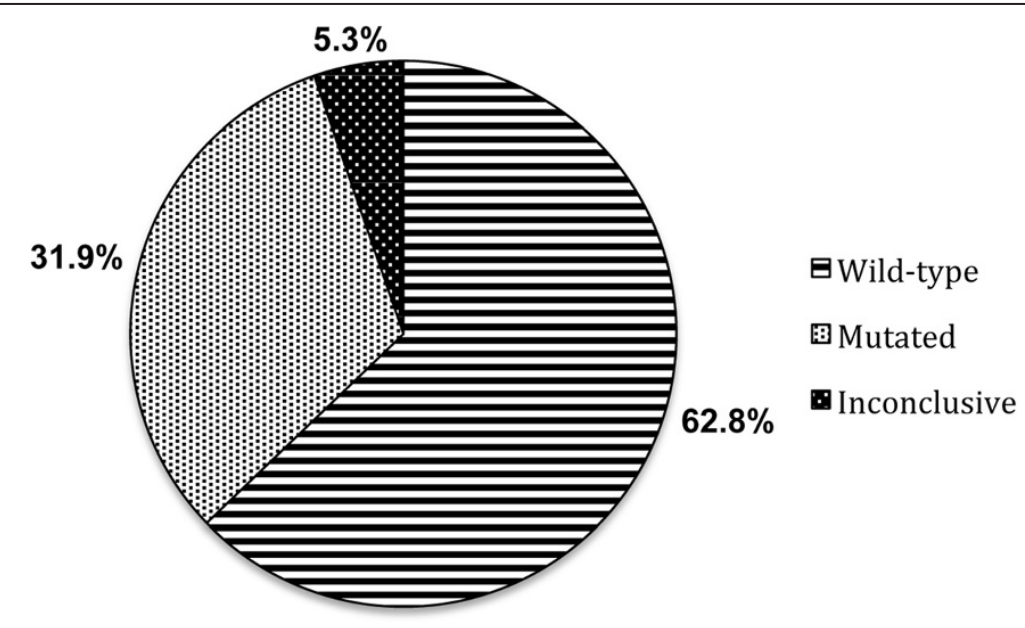

Figure 1 Overall percentage of mutant versus wild-type KRAS cases. A total of 8,234 samples were pooled for analysis and 437 tests presented an inconclusive KRAS diagnostic. 
Table 1 Geographic distribution of KRAS status according to region

\begin{tabular}{lccc}
\hline $\begin{array}{l}\text { Geographic } \\
\text { distribution }\end{array}$ & $\begin{array}{c}\text { Wild-type } \\
\mathbf{n}(\%)\end{array}$ & $\begin{array}{c}\text { Mutant } \\
\mathbf{n ~ ( \% )}\end{array}$ & $\begin{array}{c}\text { Total } \mathbf{n}(\%) \\
\mathbf{8 , 2 3 4}(\mathbf{1 0 0})\end{array}$ \\
\hline Southeast & $3,026(65.3)$ & $1,608(34.7)$ & $4,634(56.3)$ \\
South & $1,091(68)$ & $514(32)$ & $1,605(19.5)$ \\
Northeast & $558(69.1)$ & $250(30.9)$ & $808(9.8)$ \\
Middle west & $387(66.5)$ & $195(33.5)$ & $582(7.1)$ \\
North & $93(65.5)$ & $49(34.5)$ & $142(1.7)$ \\
Missing data & - & - & $463(5.6)$ \\
\hline
\end{tabular}

have analysed the importance of codon 61 (less frequently found mutated in CRC) [18], at the time we started our study mutational analysis of KRAS codons 12 and 13 was standard for patients with mCRC.

The correlation between geographic distribution and KRAS mutations was available for 8,208 tests $(99.7 \%$ of all performed tests). Overall, the mutation Gly12Asp (GGT > GAT) was the highest in most regions with the exception of the North where Gly12Val (GGT > GTT) was the most frequent. The Middle West region showed the highest percentage of Gly12Asp (GGT > GAT) mutations, whereas the North showed the least. At codon 13, the most prevalent modification was Gly13Asp (GGC > GAC), followed by other low frequent alterations. The percentage of mutations according to each region ranged from $30.9 \%$ (Northeast) to $34.7 \%$ (Southeast). Details on the distribution and types of mutations are described in Table 2.

\section{Distribution of different KRAS mutations according to gender}

Gender was tested as one of the factors that could be relevant in our analysis since it is known that in different populations, women and men are affected differently by
CRC, where men are at higher risk [19]. Table 3 shows that mutations in codon 12 were much more prevalent than in codon 13 (83\% and 17\%, respectively) and the distribution of mutations according to both codons did not differ by gender $(p=0.34)$. Overall, the most frequent point mutation in codon 12 was Gly12Asp (GGT > GAT), being found in $36.4 \%$ of all mutant samples followed by Gly12Val (GGT > GTT) (24.3\%) and Gly12Cys (GGT > TGT) (7.9\%). In codon 13, Gly13Asp (GGC > GAC) was the most common mutation (16.1\%). The KRAS mutation profile according to gender correlated well with the overall KRAS mutant type, being Gly12Asp (GGT > GAT) the most frequent mutation in each gender. A detailed description of the mutations identified is shown in Table 3.

\section{Association between gender, KRAS mutation and age}

Our results have shown that the Gly12Asp mutation was the most prevalent for males and females, thus we further investigated this by analysing the overall incidence of mutant cases according to gender. The most striking result observed in our database was the fact that KRAS mutations affected more women compared to men $(34.8 \%$ vs. $32.5 \%$, respectively, $\mathrm{p}=0.03$ ) as can be seen in Table 4 .

This result led us to stratify the mutant cases also according to age, since sex hormones play an important role during a life cycle especially during female reproductive events. The age groups were $\leq 40,40-50,50-60$, $60-70$ and $\geq 70$.

Figure 2 examines the mutational status differences observed according to age and sex. Corroborating results shown in Table 4, the percentages of mutations in females are higher for the ages $\leq 40(p=0.27), 40-50(p=0.02)$ and 50-60 ( $\mathrm{p}=0.02)$ when compared to males. In contrast, ages 60-70 $(\mathrm{p}=0.47)$ and $\geq 70(\mathrm{p}=0.73)$ showed a different result, where more males have mutations.

Table 2 Incidence of KRAS mutations according to region

\begin{tabular}{|c|c|c|c|c|c|}
\hline \multirow{2}{*}{ Mutation } & Middle west n (\%) & Northeast $\mathrm{n}(\%)$ & North n (\%) & Southeast n (\%) & South n (\%) \\
\hline & $195(100)$ & $250(100)$ & $49(100)$ & $1,610(100)$ & $515(100)$ \\
\hline Gly12Asp (GGT > GAT) & $79(40.5)$ & 99 (39.6) & 15 (30.6) & $587(36.5)$ & 174 (33.8) \\
\hline Gly12Val (GGT> GTT) & $48(24.6)$ & $53(21.2)$ & $16(32.7)$ & $397(24.7)$ & $124(24.1)$ \\
\hline Gly12Cys (GGT > TGT) & $14(7.2)$ & $21(8.4)$ & $6(12.2)$ & $114(7.1)$ & $50(9.7)$ \\
\hline Gly12Ala (GGT > GCT) & $12(6.2)$ & $14(5.6)$ & $1(2)$ & $90(5.6)$ & $32(62)$ \\
\hline Gly12Ser (GGT > AGT) & $12(6.2)$ & $24(9.6)$ & $4(8.2)$ & $125(7.8)$ & $29(5.6)$ \\
\hline Gly12Arg (GGT > CGT) & $6(3.1)$ & $5(2)$ & $2(4.1)$ & $16(1)$ & $5(1)$ \\
\hline Gly13Asp (GGC > GAC) & $24(2.3)$ & $34(13.6)$ & $4(8.2)$ & $264(16.4)$ & $96(18.6)$ \\
\hline Gly13Cys (GGC > TGC) & 0 & 0 & 0 & $11(0.7)$ & $2(0.4)$ \\
\hline Gly13Ser (GGC > AGC) & 0 & 0 & $1(2)$ & $3(0.2)$ & $1(0.2)$ \\
\hline Gly13Val (GGC > GTT) & 0 & 0 & 0 & $1(0.1)$ & $1(0.2)$ \\
\hline Gly13Arg (GGC > CGC) & 0 & 0 & 0 & $2(0.1)$ & $1(0.2)$ \\
\hline Total/region (100) & $33.5 \%$ & $30.9 \%$ & $34.5 \%$ & $34.7 \%$ & $32.0 \%$ \\
\hline
\end{tabular}


Table 3 Frequency of KRAS mutations and types of alterations according to gender

\begin{tabular}{|c|c|c|c|}
\hline KRAS mutation type & $\begin{array}{c}\text { Female } \\
\text { n (\%) } \\
1,305(100)\end{array}$ & $\begin{array}{c}\text { Male } \\
\text { n (\%) } \\
1,318(100)\end{array}$ & $\begin{array}{c}\text { Total mutation } \\
\text { n (\%) } \\
2,623(100)\end{array}$ \\
\hline Codon 12 & $1,082(83)$ & $1,093(83)$ & $2,175(83)$ \\
\hline Gly12Asp (GGT > GAT) & 457 (35) & $498(37.8)$ & $955(36.4)$ \\
\hline Gly12Val (GGT > GTT) & $312(23.9)$ & $325(24.7)$ & $637(24.3)$ \\
\hline Gly12Ser (GGT > AGT) & $102(7.8)$ & $92(7)$ & $194(7.4)$ \\
\hline Gly12Ala (GGT > GCT) & $78(6)$ & $71(5.4)$ & $149(57)$ \\
\hline Gly12Cys (GGT > TGT) & $112(8.6)$ & $94(7.1)$ & $206(7.9)$ \\
\hline Gly12Arg (GGT > CGT) & $21(1.6)$ & $13(1)$ & $34(1.3)$ \\
\hline Codon 13 & $223(17)$ & $224(17)$ & $447(17)$ \\
\hline Gly13Asp (GGC > GAC) & $215(16.5)$ & $208(15.8)$ & $423(16.1)$ \\
\hline Gly13Cys (GGC > TGC) & $3(0.2)$ & $10(0.8)$ & $13(0.5)$ \\
\hline Gly13Ser (GGC > AGC) & $3(0.2)$ & $3(0.2)$ & $6(0.2)$ \\
\hline Gly13Val (GGC > GTT) & $1(0.1)$ & $1(0.1)$ & $2(0.1)$ \\
\hline Gly13Arg (GGC > CGC) & $1(0.1)$ & $2(0.2)$ & $3(0.1)$ \\
\hline Gly12Ser (GGT> TTT)* & - & - & 1 \\
\hline
\end{tabular}

*Missing data.

However, in this case the differences in percentage within the age ranges were less dramatic $(60-70=35.1 \%$ vs $33.6 \%$; $\geq 70=33.9 \%$ vs $33.1 \%$; male vs female) than the ones observed between males and females in the range $\leq 40(30.3 \%$ vs $34.3 \% ; \mathrm{p}=0.27), 40-50(30.8 \%$ vs $37 \% ; \mathrm{p}=0.02)$, $50-60(31.3 \%$ vs $36.1 \% ; \mathrm{p}=0.02)$.

\section{Discussion}

In the colorectal carcinogenesis model initially described by Vogelstein [20], specific genetic events would be related to morphological tissue changes. Among these genetic changes, different studies have shown that mutations in the KRAS gene were found in over $30 \%$ of CRC and advanced adenomas [21,22]. The present study is consistent with this showing that among the 8,234 cases analysed, a total of 2,623 (31.9\%) corresponded to mutant KRAS (Figure 1). From the 2,623 mutated cases, $83 \%$ were in codon 12 versus $17 \%$ in codon 13 , being the aminoacid change Gly to Asp the most common for both codons and genders (Table 3). The prevalence of Gly12Asp mutation over other mutations corroborates with data from other populations around the world $[23,24]$. Despite variations in the frequency of types of mutations per region (Table 2), our results showed that

Table 4 KRAS status according to gender

\begin{tabular}{lccc}
\hline \multirow{2}{*}{ Gender } & KRAS wild-type $\mathbf{n}(\%)$ & KRAS mutant $\mathbf{n}(\%)$ & Total $\mathbf{n}(\%)$ \\
& $\mathbf{5 , 1 7 4 ( 6 6 . 4 )}$ & $\mathbf{2 , 6 2 3 ( 3 3 . 6 )}$ & $\mathbf{7 , 7 9 7 ( 1 0 0 )}$ \\
\hline Female & $2,440(65.2)$ & $1,305(34.8)$ & $3,745(100)$ \\
Male & $2,734(67.5)$ & $1,318(32.5)$ & $4,052(100)$ \\
\hline
\end{tabular}

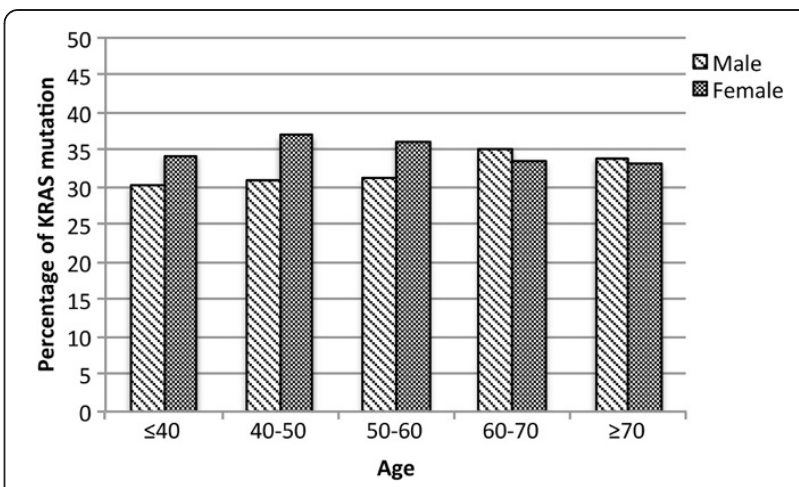

Figure 2 Percentage of mutant KRAS cases according to sex and age. Variables such as gender and age were analysed and the age ranges for both sexes were: $\leq 40(p=0.27), 40-50(p=0.02)$, 50-60 ( $p=0.02), 60-70(p=0.47)$ and $\geq 70(p=0.73)$.

more than $30 \%$ of the patients in each region harboured KRAS mutations (Table 1). Regarding prognosis, previously published data showed that Gly12Val substitutions are more aggressive having a poorer prognosis than those with Gly12Asp mutation, thus revealing a connection between survival and KRAS mutation type [23,25-27]. In relation to codon 13, some studies have shown that mutations in this codon could be less aggressive than in codon 12 and that patients with KRAS Gly13Asp mutant tumours could benefit from anti-EGFR therapies $[28,29]$. In addition, recent in vitro studies have confirmed that Gly13Asp mutations are associated with sensitivity to anti-EGFR antibody treatments [30,31]. Unfortunately, we were unable to provide prognosis comparisons since we could not retrieve the follow up from many patients in our cohort.

Gender was another variable we analysed in our cohort. The percentages of KRAS mutations pointed out a female over male prevalence (Table $4, \mathrm{p}<0.05$ ). Actually, the female predominance of KRAS mutations in CRC patients has been reported in few recent studies performed in smaller cohorts from Asia. In China, a cohort of 167 CRC patients were tested for mutations on KRAS codons 12 and 13 and their results detected a higher rate of KRAS mutations in female compared to male patients [32] and this finding did not significantly correlate with the patient age, tumour site, differentiation grades and histological types. Differently to our data, their results referred to Gly13Asp as the most frequently mutation identified [32]. In another Chinese study, Shen et al. [33] observed that in a cohort of 118 CRC patients, there was also a higher incidence of KRAS mutations in female patients compared to male patients $(44.7 \%$ vs $28.2 \%$, $\mathrm{p}=$ 0.037). In Japan, researchers suggested that gender and age were independent risk factors for KRAS mutations [34]. Another publication did not show correlation between gender and KRAS mutational status [35], and one 
possible explanation for this could be the ethnological differences in populations studied. Nevertheless, it is important to address that the greatest prevalence of KRAS mutation in women has been previously observed in other cancer types such as in patients with lung adenocarcinoma, leading to the hypothesis of possible hormonal influence [36].

Clinical evidence suggests potential sex-related differences in the development and prognosis of CRC, which could be associated with sex hormones. Estrogens and androgens regulate growth, differentiation and functioning of different tissues, including the gastrointestinal tract. Estrogen is an important mitogen capable of sending its signal to the nucleus via interaction with estrogen receptors (ER) on target cells. The two distinct estrogen receptors (ER $\alpha$ and $E R \beta)$ tend to respond differently to estrogen. The high proliferative activity triggered by estrogen is related to its connection to the ER $\alpha$, which can help tumoral development by increasing the probability of genetic mutations [37]. In contrast, the ER $\beta$ forms heterodimers with the ER $\alpha$ blocking their proliferative activity by suppression of oncogenic transcription factors (e.g. c-myc, cyclin D1 e cyclin A) and by stimulating the expression of tumour suppressing genes (e.g. p21 e p27) [38]. The expression of the ER $\beta$ is significantly reduced in adenomatous tissues and in colon tumours, when compared to normal mucosa in both genders, however with a slight reduction in females $(\mathrm{p}<0.002)$ [39-41]. Nevertheless, there are no observed changes in the expression of ER $\alpha$ between the different tissues. Also in pre-cancerous lesions with a high risk of CRC development, a decrease in ER $\beta$ expression could indicate a promoting factor for the development of cancer [42]. In hereditary nonpolyposis colon cancer syndrome (HNPCC) characterised by a dominant susceptibility acquired in the early appearance of symptoms of CRC, the average age for CRC diagnosis is earlier in males than females (38.8 vs 47.2; $\mathrm{p}<0.05)$ [19], indicating that female sexual hormones could be acting as protective factors. This estrogen protectiveness was also the conclusion after guinea pigs that were treated with PhiP (2-Amino-1-methyl-6-phenylimidazo [4,5-b] pyridine), an inducing agent for colon cancer, resulted in the average number of aberrant crypt foci higher in males than in females $(p<0.001)$ [43]. In regard to hormone replacement therapy, meta-analysis studies have confirmed the reverse association with the risk of developing CRC [44-47].

The role that male sexual hormones play in the risk for CRC is still unclear. There is evidence of reverse association between the serum level of the dehydroepiandrosterone sulfate and the risk of CRC [48]. The increase of CAG trinucleotide repetitions in the coding sequence of the androgen receptor seems to be related to the lowest trancriptional activation of this receptor resulting in a lower androgenic action on the tissues, increasing the risk of developing colon cancer [49]. Gillessen et al. [50] confirmed in a large retrospective evaluation of 107,859 patients with prostate cancer that patients treated with Gonadotrophin-releasing hormone $(\mathrm{GnRH})$ antagonist or orchiectomy presented an increase of $30-40 \%$ risk of developing CRC when compared to the subgroup that were not submitted to androgenic deprival.

Kato et al. [51,52] showed that the estrogen receptor is involved in the KRAS mediated transcription and its implication in the senescence escape. Furthermore, an association between KRAS and estrogen receptor was also observed when mutant KRAS (Gly12Val) was overexpressed in NIH-3 T3 cells, which resulted in increased levels of the endogenous estrogen receptor. In addition, the RAS signal intensified the estrogen receptor activity as a transcription factor leading to cell transformation [53]. In a pre-clinical study it was shown that RAS oncogenes might remain latent in the mammary gland of guinea pigs until estrogen exposure. This suggests that normal proliferative processes, such as the ones induced by estrogen in the development of the mammary gland, could be necessary to lead cells with the latent RAS oncogenes to neoplastic development [54]. Collectively, these findings could indicate an association between mutant KRAS and sexual hormones.

Our observations of differences in KRAS mutational status according to sex led us to analyse also age. KRAS was more frequently found mutated in females than males for the ages $\leq 40,40-50$, and $50-60$ (Figure 2). The age range 40-60 coincides with the menopausal period, which is associated with a drop in estrogen levels. In contrast, ages $60-70$ and $\geq 70$ showed a different result, where males had more mutations than females $(p>0.05)$. Although the $p$ value was higher for the ages $60-70$ and $\geq 70$, this result could indicate an agelinked difference associated with several causes including men andropause. Actually, a recent study suggested that men with lower androgenicity (resulting either from reduced androgen receptor activity or lower circulating dehydroepiandrosterone sulfate) have a higher risk for colorectal cancer, however they did not correlate the hormonal influence with levels of gene mutations [55]. One theory to explain our results could be that male and female hormones may act as protective factors not exerting pressure on the expansion of KRAS mutant cells. However, upon menopause and andropause (events that occur at different ages for males and females) the decrease in hormonal levels could generate a pressure to stimulate a molecular switch in favour of clonal selection of cells containing KRAS mutations. Nevertheless, future studies on a large cohort corresponding to late age ranges are necessary to further confirm these results. 


\section{Conclusions}

We found that variables such as region, age and sexlinked factors can correlate with KRAS mutational status. This is the largest study to point out a statistically difference in the prevalence of KRAS mutations between genders in a cohort of brazilian mCRC patients. The exact interaction between KRAS mutations, sexual hormones and the development of CRC is still not well defined. In the adenoma-carcinoma sequence, the proliferative hormonal exposure in the presence of ER $\alpha$ and the decrease of ER $\beta$ could be a factor to select KRAS mutant clones in the adenocarcinoma histologic subtype in females. Although estrogen could serve as a protective hormone in CRC, it might not prevent mutations in KRAS. Our group is currently evaluating experimentally the reasons behind the differences observed in this study. Hopefully, future research will be able to elucitate the molecular links between hormones, KRAS mutations, age and CRC development.

\section{Abbreviations}

CRC: Colorectal cancer; ER: Estrogen receptors; GnRH: Gonadotrophin-releasing hormone; PhiP: 2-Amino-1-methyl-6-phenylimidazo [4,5-b] pyridine.

\section{Competing interests}

We acknowledge that there are no known conflicts of interest associated with this publication.

\section{Authors' contributions}

Study design and coordination: CGF, MZ. Acquisition of data: CGF, VA, IZR, APV, JHS, MHB, FMV, MZ. Statistical analysis: JHS. Analysis and interpretation of data: CGF, VA, FMV. Wrote the paper: VA, FMV, CGF, MZ. Critical revision of manuscript: CGF, VA, IZR, APV, JHS, MHB, FMV, MZ. Final approval of manuscript: CGF, VA, IZR, APV, JHS, MHB, FMV, MZ. All authors read and approved the final manuscript.

\section{Acknowledgements}

We would like to thank Fundação Ary Frauzino (Brazilian Cancer Foundation), Ministério da Saúde (Brazil) and Merck Serono for their support.

\section{Author details}

'Progenética Diagnósticos Moleculares, Av. Presidente Vargas, 9623 Andar, Cep: 20071-002 Rio de Janeiro, RJ, Brazil. ²Brazilian National Cancer Institute (INCA); Coordenação de Pesquisa Clínica e Incorporação Tecnológica, Rio de Janeiro, Brazil. ${ }^{3}$ Divisão de Medicina Experimental, Brazilian National Cancer Institute (INCA), Rio de Janeiro, Brazil. ${ }^{4}$ Instituto COI de Educação e Pesquisa, Rio de Janeiro, Brazil.

\section{Received: 14 November 2013 Accepted: 2 April 2014}

Published: 10 April 2014

\section{References}

1. Ely S: Personalized medicine: individualized care of cancer patients. Trans/ Res 2009, 154(6):303-308.

2. Winer E, Gralow J, Diller L, Karlan B, Loehrer P, Pierce L, Demetri G, Ganz P, Kramer B, Kris M, Markman M, Mayer R, Pfister D, Raghavan D, Ramsey S, Reaman G, Sandler H, Sawaya R, Schuchter L, Sweetenham J, Vahdat L, Schilsky RL: Clinical cancer advances 2008: major research advances in cancer treatment, prevention, and screening-a report from the American Society of Clinical Oncology. J Clin 2009, 27(5):812-826.

3. Karapetis CS, Khambata-Ford S, Jonker DJ, O'Callaghan CJ, Tu D, Tebbutt NC, Simes RJ, Chalchal H, Shapiro JD, Robitaille S, Price TJ, Shepherd L, Au HJ, Langer C, Moore MJ, Zalcberg JR: K-ras mutations and benefit from cetuximab in advanced colorectal cancer. N Engl J Med 2008, 359(17):1757-1765.
4. Siegel R, Naishadham D, Jemal A: Cancer statistics, 2012. CA Cancer J Clin 2012, 62(1):10-29.

5. Palomba G, Colombino M, Contu A, Massidda B, Baldino G, Pazzola A, lonta M, Capelli F, Trova V, Sedda T, Sanna G, Tanda F, Budroni M, Sardinian Translational Oncology Group (STOG), Palmieri G, Cossu A, Contu M, Cuccu A, Farris A, Macciò A, Mameli G, Olmeo N, Ortu S, Petretto E, Pusceddu V, Virdis L: Prevalence of KRAS, BRAF, and PIK3CA somatic mutations in patients with colorectal carcinoma may vary in the same population: clues from Sardinia. J Transl Med 2012, 10:178.

6. Aran V, Prior IA: Compartmentalized Ras signaling differentially contributes to phenotypic outputs. Cell Signal 2013, 25(9):1748-1753.

7. Prior IA, Lewis PD, Mattos C: A comprehensive survey of Ras mutations in cancer. Cancer Res 2012, 72(10):2457-2467.

8. Benvenuti S, Sartore-Bianchi A, Di Nicolantonio F, Zanon C, Moroni M, Veronese S, Siena S, Bardelli A: Oncogenic activation of the RAS/RAF signaling pathway impairs the response of metastatic colorectal cancers to anti-epidermal growth factor receptor antibody therapies. Cancer Res 2007, 67(6):2643-2648.

9. Van Cutsem E, Kohne CH, Hitre E, Zaluski J, Chang Chien CR, Makhson A, D'Haens G, Pinter T, Lim R, Bodoky G, Roh JK, Folprecht G, Ruff P, Stroh C, Tejpar S, Schlichting M, Nippgen J, Rougier P: Cetuximab and chemotherapy as initial treatment for metastatic colorectal cancer. N Engl J Med 2009, 360(14):1408-1417.

10. De Roock W, Claes B, Bernasconi D, De Schutter J, Biesmans B, Fountzilas G, Kalogeras KT, Kotoula V, Papamichael D, Laurent-Puig P, Penault-Llorca F, Rougier P, Vincenzi B, Santini D, Tonini G, Cappuzzo F, Frattini M, Molinari F, Saletti P, De Dosso S, Martini M, Bardelli A, Siena S, Sartore-Bianchi A, Tabernero J, Macarulla T, Di Fiore F, Gangloff AO, Ciardiello F, Pfeiffer P, et al: Effects of KRAS, BRAF, NRAS, and PIK3CA mutations on the efficacy of cetuximab plus chemotherapy in chemotherapy-refractory metastatic colorectal cancer: a retrospective consortium analysis. Lancet Oncol 2010, 11(8):753-762.

11. Siena S, Sartore-Bianchi A, Di Nicolantonio F, Balfour J, Bardelli A: Biomarkers predicting clinical outcome of epidermal growth factor receptor-targeted therapy in metastatic colorectal cancer. J Natl Cancer Inst 2009, 101(19):1308-1324.

12. Bokemeyer C, Bondarenko I, Makhson A, Hartmann JT, Aparicio J, de Braud F, Donea S, Ludwig H, Schuch G, Stroh C, Loos AH, Zubel A, Koralewski P: Fluorouracil, leucovorin, and oxaliplatin with and without cetuximab in the first-line treatment of metastatic colorectal cancer. J Clin Oncol 2009, 27(5):663-671.

13. Amado RG, Wolf M, Peeters $M$, Van Cutsem $E$, Siena S, Freeman DJ, Juan T, Sikorski R, Suggs S, Radinsky R, Patterson SD, Chang DD: Wild-type KRAS is required for panitumumab efficacy in patients with metastatic colorectal cancer. J Clin Oncol 2008, 26(10):1626-1634.

14. Siddiqui $A D$, Piperdi $B$ : KRAS mutation in colon cancer: a marker of resistance to EGFR-I therapy. Ann Surg Oncol 2010, 17(4):1168-1176.

15. Allegra CJ, Jessup JM, Somerfield MR, Hamilton SR, Hammond EH, Hayes DF, McAllister PK, Morton RF, Schilsky RL: American Society of Clinical Oncology provisional clinical opinion: testing for KRAS gene mutations in patients with metastatic colorectal carcinoma to predict response to anti-epidermal growth factor receptor monoclonal antibody therapy. J Clin Oncol 2009, 27(12):2091-2096.

16. Alves-Silva J, da Silva SM, Guimaraes PE, Ferreira AC, Bandelt HJ, Pena SD Prado VF: The ancestry of Brazilian mtDNA lineages. Am J Hum Genet 2000, 67(2):444-461.

17. Pena SD, Di Pietro G, Fuchshuber-Moraes M, Genro JP, Hutz MH, Kehdy Fde S, Kohlrausch F, Magno LA, Montenegro RC, Moraes MO, de Moraes ME, de Moraes MR, Ojopi EB, Perini JA, Racciopi C, Ribeiro-Dos-Santos AK, Rios-Santos F, Romano-Silva MA, Sortica VA, Suarez-Kurtz G: The genomic ancestry of individuals from different geographical regions of Brazil is more uniform than expected. PLoS One 2011, 6(2):e17063.

18. Douillard JY, Oliner KS, Siena S, Tabernero J, Burkes R, Barugel M, Humblet Y, Bodoky G, Cunningham D, Jassem J, Rivera F, Kocákova I, Ruff P, BłasińskaMorawiec M, Šmakal M, Canon JL, Rother M, Williams R, Rong A, Wiezorek J, Sidhu R, Patterson SD: Panitumumab-FOLFOX4 treatment and RAS mutations in colorectal cancer. N Engl J Med 2013, 369(11):1023-1034.

19. Froggatt NJ, Green J, Brassett C, Evans DG, Bishop DT, Kolodner R, Maher ER: A common MSH2 mutation in English and North American HNPCC families: origin, phenotypic expression, and sex specific differences in colorectal cancer. J Med Genet 1999, 36(2):97-102. 
20. Vogelstein B, Fearon ER, Hamilton SR, Kern SE, Preisinger AC, Leppert M, Nakamura Y, White R, Smits AM, Bos JL: Genetic alterations during colorectal-tumor development. N Engl J Med 1988, 319(9):525-532.

21. Moran A, Ortega P, de Juan C, Fernandez-Marcelo T, Frias C, SanchezPernaute A, Torres AJ, Diaz-Rubio E, Iniesta P, Benito M: Differential colorectal carcinogenesis: molecular basis and clinical relevance. World J Gastrointest Oncol 2010, 2(3):151-158.

22. Qiu LX, Mao C, Zhang J, Zhu XD, Liao RY, Xue K, Li J, Chen Q: Predictive and prognostic value of KRAS mutations in metastatic colorectal cancer patients treated with cetuximab: a meta-analysis of 22 studies. Eur J Cancer 2010, 46(15):2781-2787.

23. Winder T, Mundlein A, Rhomberg S, Dirschmid K, Hartmann BL, Knauer M, Drexel H, Wenzl E, De Vries A, Lang A: Different types of K-Ras mutations are conversely associated with overall survival in patients with colorectal cancer. Oncol Rep 2009, 21(5):1283-1287.

24. Knijn N, Mekenkamp LJ, Klomp M, Vink-Borger ME, Tol J, Teerenstra S, Meijer JW, Tebar M, Riemersma S, van Krieken JH, Punt CJ, Nagtegaal ID: KRAS mutation analysis: a comparison between primary tumours and matched liver metastases in 305 colorectal cancer patients. Br J Cancer 2011, 104(6):1020-1026.

25. Al-Mulla F, Milner-White EJ, Going JJ, Birnie GD: Structural differences between valine-12 and aspartate-12 Ras proteins may modify carcinoma aggression. J Pathol 1999, 187(4):433-438.

26. Andreyev HJ, Norman AR, Cunningham D, Oates J, Dix BR, lacopetta BJ, Young J, Walsh T, Ward R, Hawkins N, Beranek M, Jandik P, Benamouzig R, Jullian E, Laurent-Puig P, Olschwang S, Muller O, Hoffmann I, Rabes HM, Zietz C, Troungos C, Valavanis C, Yuen ST, Ho JW, Croke CT, O'Donoghue DP, Giaretti W, Rapallo A, Russo A, Bazan V, et al: Kirsten ras mutations in patients with colorectal cancer: the 'RASCAL II' study. Br J Cancer 2001, 85(5):692-696

27. Andreyev HJ, Norman AR, Cunningham D, Oates JR, Clarke PA: Kirsten ras mutations in patients with colorectal cancer: the multicenter "RASCAL" study. J Natl Cancer Inst 1998, 90(9):675-684

28. Tejpar S, Celik I, Schlichting M, Sartorius U, Bokemeyer C, Van Cutsem E: Association of KRAS G13D tumor mutations with outcome in patients with metastatic colorectal cancer treated with first-line chemotherapy with or without cetuximab. J Clin Oncol 2012, 30(29):3570-3577.

29. Chen CC, Er TK, Liu YY, Hwang JK, Barrio MJ, Rodrigo M, Garcia-Toro E, Herreros-Villanueva M: Computational analysis of KRAS mutations: implications for different effects on the KRAS p.G12D and p.G13D mutations. PLoS One 2013, 8(2):e55793.

30. Messner I, Cadeddu G, Huckenbeck W, Knowles HJ, Gabbert HE, Baldus SE, Schaefer KL: KRAS p.G13D mutations are associated with sensitivity to anti-EGFR antibody treatment in colorectal cancer cell lines. J Cancer Res Clin Oncol 2013, 139(2):201-209.

31. Kumar SS, Price TJ, Mohyieldin O, Borg M, Townsend A, Hardingham JE: KRAS G13D Mutation and Sensitivity to Cetuximab or Panitumumab in a Colorectal Cancer Cell Line Model. Gastrointest Cancer Res 2014, 7(1):23-26.

32. Gao J, Zhang J, LU T, Li XY, Jia N, Liang ZY: [Correlation between KRAS mutations and clinicopathologic features in colorectal carcinomas]. Zhonghua Bing Li Xue Za Zhi 2012, 41(9):595-598.

33. Shen H, Yuan Y, Hu HG, Zhong X, Ye XX, Li MD, Fang WJ, Zheng S: Clinical significance of K-ras and BRAF mutations in Chinese colorectal cancer patients. World J Gastroenterol 2011, 17(6):809-816.

34. Watanabe T, Yoshino T, Uetake H, Yamazaki K, Ishiguro M, Kurokawa T, Saijo $\mathrm{N}$, Ohashi Y, Sugihara K: KRAS Mutational Status in Japanese patients with colorectal cancer: results from a Nationwide, Multicenter, Cross-sectional Study. Jpn J Clin Oncol 2013, 43(7):706-712.

35. Liu X, Jakubowski M, Hunt JL: KRAS gene mutation in colorectal cancer is correlated with increased proliferation and spontaneous apoptosis. Am J Clin Pathol 2011, 135(2):245-252.

36. Planchard D, Loriot $Y$, Goubar A, Commo F, Soria JC: Differential expression of biomarkers in men and women. Semin Oncol 2009, 36(6):553-565.

37. Di Leo A, Barone M, Maiorano E, Tanzi S, Piscitelli D, Marangi S, Lofano K, lerardi E, Principi M, Francavilla A: ER-beta expression in large bowel adenomas: implications in colon carcinogenesis. Dig Liver Dis 2008, 40(4):260-266

38. Paruthiyil S, Parmar H, Kerekatte V, Cunha GR, Firestone GL, Leitman DC: Estrogen receptor beta inhibits human breast cancer cell proliferation and tumor formation by causing a G2 cell cycle arrest. Cancer Res 2004, 64(1):423-428
39. Campbell-Thompson M, Lynch IJ, Bhardwaj B: Expression of estrogen receptor (ER) subtypes and ERbeta isoforms in colon cancer. Cancer Res 2001, 61(2):632-640.

40. Castiglione F, Taddei A, Rossi Degl'Innocenti D, Buccoliero AM, Bechi P Garbini F, Chiara FG, Moncini D, Cavallina G, Marascio L, Freschi G, Gian LT: Expression of estrogen receptor beta in colon cancer progression. Diagn Mol Pathol 2008, 17(4):231-236.

41. Waliszewski P, Blaszczyk M, Wolinska-Witort E, Drews M, Snochowski M, Hurst RE: Molecular study of sex steroid receptor gene expression in human colon and in colorectal carcinomas. J Surg Oncol 1997, 64(1):3-11.

42. Hartman J, Gustafsson JA: Estrogen receptors in colorectal cancer: goalkeepers, strikers, or bystanders? Cancer Prev Res (Phila) 2010, 3(8):897-899.

43. Ochiai M, Watanabe M, Kushida H, Wakabayashi K, Sugimura T, Nagao M: DNA adduct formation, cell proliferation and aberrant crypt focus formation induced by PhIP in male and female rat colon with relevance to carcinogenesis. Carcinogenesis 1996, 17(1):95-98.

44. Farquhar C, Marjoribanks J, Lethaby A, Suckling JA, Lamberts Q: Long term hormone therapy for perimenopausal and postmenopausal women. Cochrane Database Syst Rev 2009, 2, CD004143.

45. Grodstein F, Stampfer MJ, Falkeborn M, Naessen T, Persson I: Postmenopausal hormone therapy and risk of cardiovascular disease and hip fracture in a cohort of Swedish women. Epidemiology 1999, 10(5):476-480.

46. Nanda K, Bastian LA, Hasselblad V, Simel DL: Hormone replacement therapy and the risk of colorectal cancer: a meta-analysis. Obstet Gynecol 1999, 93(5 Pt 2):880-888.

47. Lin KJ, Cheung WY, Lai JY, Giovannucci EL: The effect of estrogen vs. combined estrogen-progestogen therapy on the risk of colorectal cancer. Int J Cancer 2012, 130(2):419-430.

48. Alberg AJ, Gordon GB, Hoffman SC, Comstock GW, Helzlsouer KJ: Serum dehydroepiandrosterone and dehydroepiandrosterone sulfate and the subsequent risk of developing colon cancer. Cancer Epidemiol Biomarkers Prev 2000, 9(5):517-521.

49. Slattery ML, Sweeney C, Murtaugh M, Ma KN, Wolff RK, Potter JD, Caan BJ, Samowitz W: Associations between ERalpha, ERbeta, and AR genotypes and colon and rectal cancer. Cancer Epidemiol Biomarkers Prev 2005, 14(12):2936-2942.

50. Gillessen S, Templeton A, Marra G, Kuo YF, Valtorta E, Shahinian VB: Risk of colorectal cancer in men on long-term androgen deprivation therapy for prostate cancer. J Natl Cancer Inst 2010, 102(23):1760-1770

51. Kato K, Sakamoto T, Wake N: Requirement of estrogen receptor expression and function for [12Val] K-Ras-mediated NIH3T3 cell transformation. Oncology 1998, 55(Suppl 1):45-52.

52. Kato K, Horiuchi S, Takahashi A, Ueoka Y, Arima T, Matsuda T, Kato H, Nishida Ji J, Nakabeppu Y, Wake N: Contribution of estrogen receptor alpha to oncogenic K-Ras-mediated NIH3T3 cell transformation and its implication for escape from senescence by modulating the $\mathrm{p} 53$ pathway. J Biol Chem 2002, 277(13):11217-11224.

53. Kato K, Ueoka Y, Kato K, Hachiya T, Nishida J, Wake N: Contribution of enhanced transcriptional activation by ER to [12Val] K-Ras mediated NIH3T3 cell transformation. Oncogene 1997, 15(25):3037-3046.

54. Kumar R, Sukumar S, Barbacid M: Activation of ras oncogenes preceding the onset of neoplasia. Science 1990, 248(4959):1101-1104.

55. Lin JH, Zhang SM, Rexrode KM, Manson JE, Chan AT, Wu K, Tworoger SS, Hankinson SE, Fuchs C, Gaziano JM, Buring JE, Giovannucci E: Association between sex hormones and colorectal cancer risk in men and women. Clin Gastroenterol Hepatol 2013, 11(4):419-424.

doi:10.1186/1471-230X-14-73

Cite this article as: Gil Ferreira et al:: KRAS mutations: variable incidences in a Brazilian cohort of 8,234 metastatic colorectal cancer patients. BMC Gastroenterology 2014 14:73. 